\title{
Optimization of biogas from chicken droppings with Cymbopogon citratus
}

\author{
H.I. Owamah ${ }^{\text {a,* }}$, M.I. Alfa ${ }^{\mathrm{b}}$, S.O. Dahunsi ${ }^{\mathrm{c}}$ \\ ${ }^{a}$ Department of Civil Engineering, Landmark University, P.M.B. 1001, Omu-Aran, Kwara State, Nigeria \\ ${ }^{\mathrm{b}}$ Department of Water Resources and Environmental Engineering, Ahmadu Bello University, Zaria, Kaduna State, Nigeria \\ ${ }^{\mathrm{c}}$ Department of Biological Sciences, Landmark University, Omu-Aran, Kwara State, Nigeria
}

\section{A R T I C L E I N F O}

\section{Article history:}

Received 27 August 2013

Accepted 7 February 2014

Available online 4 March 2014

\section{Keywords:}

Cymbopogon citratus

Chicken droppings

Anaerobic co-digestion

Cooking rate

Methane content

\begin{abstract}
A B S T R A C T
Optimization of biogas production and quality from chicken droppings by anaerobic co-digestion with Cymbopogon citratus was investigated. The anaerobic digestions of chicken droppings, chicken droppings with $C$. citratus as well as $C$. citratus alone were carried out for a period of 30 days at an average ambient temperature of $33.1 \pm 2{ }^{\circ} \mathrm{C}$ using identical reactors (A-C) respectively. Results obtained indicate that chicken droppings produced on the average $1.8 \mathrm{~L} / \mathrm{kg} /$ day of biogas, co-digestion of chicken droppings and C. citratus produced $1.3 \mathrm{~L} / \mathrm{kg} /$ day of biogas while $C$. citratus alone produced $1.0 \mathrm{~L} / \mathrm{kg} /$ day with estimated average methane content of $41.71 \%, 66.20 \%$ and $71.95 \%$ for reactors $\mathrm{A}-\mathrm{C}$ respectively. The water boiling rates of biogas from chicken droppings, chicken droppings with $C$. citratus, and $C$. citratus alone were $0.079 \mathrm{~L} / \mathrm{min}, 0.091 \mathrm{~L} / \mathrm{min}$ and $0.12 \mathrm{~L} / \mathrm{min}$ respectively, after the gases were scrubbed with water and slaked lime. It was observed that notwithstanding the higher biogas volumetric yield from chicken droppings digested alone, the co-digestion of chicken droppings with $C$. citratus had better gas quality with respect to the methane content present and cooking rate. This study has shown that the methane content of biogas from animal manure substrates could be improved by co-digestion with energy plants.
\end{abstract}

(c) 2014 Elsevier Ltd. All rights reserved.

\section{Introduction}

Inadequate energy supply and environmental pollution are gargantuan problems confronting Nigeria and many other developing nations of the world. The energy demanding lifestyle of the modern world calls for the generation of energy from alternative sources that are renewable and eco-friendly [1]. The abundant hydrocarbon natural resource (crude oil and natural gas) in Nigeria is the mainstay of over $80 \%$ of revenues to the nation. However, this has neither served as a catalyst for economic growth nor the major source of energy in the mix of energy supplies. Rising crude oil prices, environmental pollution resulting from the exploration, processing and utilization of crude oil and its products have forced nations of the world to think about alternative sources of energy. Economic growth and the resultant heavy consumption of natural resources are responsible for pollution, global warming and production of acid rain etc [2]. There is a consensus of opinion that achieving the Millennium Development Goals (MDGs) in Africa will

\footnotetext{
* Corresponding author. Tel.: +2348035705814.

E-mail addresses: dahilla222@yahoo.com, owamah.hilary@gmail.com (H.I. Owamah).
}

require a significant expansion of access to modern and alternative renewable energy [3]. Biogas energy could serve this purpose and can also be managed by locally available resources and simple technology especially for rural villages [3]. Furthermore, the need for adequate sanitation and energy especially in sub-Saharan Africa where only $36 \%$ of the population is served with improved sanitation facilities and only $58 \%$ are served with a safe and clean water supply [4,5] has made biogas technology a welcome development.

Anaerobic digestion is one of the few biotechnologies that can simultaneously produce bioenergy (as methane biogas), reduce environmental pollution and recycle nutrients. However, the industrial viability of this process requires a suitable combination of physical and chemical process parameters and a low-cost substrate, hence the need for process optimization. Attempts have been made to improve biogas production using mixed co-substrates. Anaerobic co-digestion of a simulated organic fraction of municipal solid wastes and fats of animal and vegetable origin has been reported [6]. A substrate of kitchen waste with cow manure has been used to achieve a yield increase of $44 \%$ [7]. Kaparaju and Rintala [8] have examined the co-digestion of pig manure, potato tuber and its industrial by-products. The co-digestion of fruit and vegetable wastes, cattle slurry and chicken manure or sewage sludge for 
Table 1

Characteristics of the substrates before anaerobic digestion.

\begin{tabular}{|c|c|c|c|c|c|}
\hline $\mathrm{S} / \mathrm{N}$ & Parameter & Poultry droppings & Poultry droppings + Cymbopogon citratus & Cymbopogon citratus & Inoculum \\
\hline 1 & $\mathrm{pH}$ & $6.3 \pm 0.1$ & $5.1 \pm 0.1$ & $6.5 \pm 0.1$ & $7.8 \pm 0.1$ \\
\hline 2 & Total solids $(\% w / w)$ & $68 \pm 5.6$ & $19 \pm 2.1$ & $3 \pm 0.1$ & $1.62 \pm 0.1$ \\
\hline 3 & Volatile solids $(\% w / w)$ & $37.4 \pm 3.2$ & $8.6 \pm 1.6$ & $1.2 \pm 0.01$ & $90.72 \pm 5.9$ \\
\hline 4 & Ash $(\% w / w)$ & $2.43 \pm 0.1$ & $2.8 \pm 0.1$ & $3.1 \pm 0.1$ & $1.24 \pm 0.1$ \\
\hline 5 & Total Kjeldahl nitrogen (gN/kg) & $72.2 \pm 8.5$ & $38.5 \pm 2.9$ & $12.0 \pm 1.8$ & $14.2 \pm 1.9$ \\
\hline 6 & Alkalinity (g/L) & $28.2 \pm 2.3$ & $16.0 \pm 2.1$ & 0 & $4.4 \pm 0.4$ \\
\hline 7 & $\mathrm{C}: \mathrm{N}$ ratio & $4.2 \pm 0.2$ & $42.2 \pm 3.6$ & $76.4 \pm 4.8$ & $3.8 \pm 0.3$ \\
\hline 8 & Protein $(\% w / w)$ & $4.2 \pm 0.2$ & $3.1 \pm 0.1$ & $0.84 \pm 0.1$ & $2.6 \pm 0.1$ \\
\hline 9 & Carbohydrate $(\% w / w)$ & $2.4 \pm 0.1$ & $12.3 \pm 0.2$ & $16 \pm 1.2$ & $2.2 \pm 0.1$ \\
\hline
\end{tabular}

biogas production has also been studied $[9,10]$. The best combination of various substrates for optimal yield and gas quality remains a big problem despite the enormous number of potential substrates. The technical and economical feasibility of an industrial anaerobic digestion plant has been reported to be dependent on the methane content of the biogas generated [11]. Co-digestion of different materials may enhance the anaerobic digestion process due to better carbon and nutrient balance $[12,13]$.

Cymbopogon citratus popularly known as lemon grass is an aromatic plant belonging to the family Gramineae and the genus Cymbopogon [14]. It is a perennial grass growing to a height of about $1 \mathrm{~m}$. The leaf-blade is linear, tapered at both ends and can grow to a length of $50 \mathrm{~cm}$ and width of $1.5 \mathrm{~cm}$ [15]. The leaf-sheath is tubular in shape and acts as a pseudo stem. It is native of the warm temperate and tropical regions of the old world. Lemon grass can tolerate a wide range of soils and climatic conditions but grows more vigorously on fertile well drained sandy loam soil [15].

According to Ref. [16], lemon grass is used for many medical and industrial applications due to its essential oil and citral content. However, after using lemon grass for its useful purposes, it is often discarded as solid waste in huge quantities. At the moment little or less is known on the re-use of lemon grass waste. There is also paucity of information on the potential of $C$. citratus (lemon grass) for biogas production. Though chicken droppings could yield relatively large amount of biogas, its biogas usually contains a lot of impurities. Co-digesting chicken droppings with some energy plants could contribute to improving the quality of biogas generated. This study was therefore carried out to investigate the effect of co-digesting chicken droppings and $C$. citratus (lemon grass) on biogas quality (methane content and heating capacity). The viability of large scale anaerobic plants depends not only on biogas yield but also improved gas quality [17].

\section{Materials and method}

\subsection{Collection and preparation of substrates}

Chicken droppings were obtained (fresh and free from impurities such as wood filings) from the Poultry Department (Deep litter section) of the National Animal Production Research Institute, Shika-Zaria, Nigeria and were transported to the research site. The C. citratus (lemon grass) on the other hand was obtained from gardens around some houses within Area BZ staff quarters, Ahmadu Bello University, Zaria. The total solids and volatile solids of substrates were determined using standard methods described in Ref. [17,18]. Following the procedure in Fantozzi and Buratti [11]; APHA [18] the carbon and nitrogen contents were determined using a TruSpec-CHN LECO analyzer. Ash content was determined using TGA 701 LEO analyzer [11,18]. Total Kjeldahl Nitrogen (TKN) was measured using standard methods [18]. Protein and carbohydrate contents were measured using Soxhlet extraction and microKjeldahl methods described in Uzodinma and Ofoefule [19]. With slight modification, the procedure used in Kaparaju and Rintala [8] was used to measure the methane content of biogas by gas chromatography (GC) (Agilent Technologies 6890N, Ca, USA) using flame ionization detection (FID) fitted with a Porapak Molsieve 5A columns. Helium was used as carrier gas with a pressure of $3.0 \mathrm{~kg} /$ $\mathrm{cm}^{2}$ and flow rate of $15 \mathrm{ml} / \mathrm{min}$. Injection and detection temperatures were set at $105^{\circ} \mathrm{C}$ and $150^{\circ} \mathrm{C}$ respectively. Detailed characteristics of the substrates are shown in Table 1. The lemon grass obtained was kept in a dry bucket and was allowed to degrade for 40 days, before it was crushed to smaller particles (about 2 inches or less) using hammer mill. Similar procedure was used for field grass [19]. The poultry droppings were sun dried for 15 days, followed by mechanical crushing with mortar and pestle. Lemon grass was allowed to degrade for 40 days inorder to partially decompose its lignin, cellulose and other fibrous tissues to enhance a better performance during the anaerobic digestion.

\subsection{Experimental device}

Three 25 L-biogas reactors $(A-C)$ each of height $0.5 \mathrm{~m}$ and diameter $0.25 \mathrm{~m}$ were fabricated from galvanized steel. Galvanized steel was used as building material because of its strength and durability in acid or basic environment. Five different holes were bored on the lid of the digester for insertion of temperature and $\mathrm{pH}$ probes using threaded steel adapters and rubber stoppers to avoid gas leakage. The cylindrical shape was adopted to enhance better mixing. The tank was air tight and was clearly placed above the ground level where it was exposed to sunlight for partial heating. Three 12.1 L gas holder tanks each of height $0.25 \mathrm{~m}$ and diameter $0.25 \mathrm{~m}$ were fabricated from thin sheet metal and were used to temporarily store the biogas until it was used to produce heat or used to replace or supplement the supply of cooking gas. Plastic hose was used to connect the digester to the gas collection system and the biogas stove burner while plastic valves were installed to control the gas flow. The gas holder stores the biogas and allows the volume of biogas produced to be measured through the indirect measurement of a liquid column height. The digester and gas holder were designed, built and operated by the methods described in Ref. $[17,20]$ with slight modifications. The composition of biogas $\left(\mathrm{CH}_{4}\right.$ and $\mathrm{CO}_{2}$ contents) was determined using a gas chromatography (GC) (Agilent Technologies 6890N, Ca, USA). Biogas composition measurement was taken two times a week in duplicate from each digester. A $100 \mu \mathrm{l}$ gas tight syringe was used to take biogas samples from the digesters head space after releasing the gas. This was followed by injecting the biogas sample into the GC [21,22]. The other materials used in this study include $\mathrm{pH}$ meter model pHS-2S, (Shanghai Jinyke Rex, China) for measuring the $\mathrm{pH}$ of slurry every week day throughout the retention period, and Uniscope $2 / 1{ }^{\circ} \mathrm{C}$ thermometers was used to obtain daily temperature of the digester as well as the daily ambient temperatures of the environment. The schematic of the set-up is as shown in Fig. 1. 


\subsection{Experimental design and set-up}

Batch anaerobic digestion tests were carried out on chicken droppings, mixture of chicken droppings and $C$. citratus, and $C$. citratus alone in reactors $\mathrm{A}-\mathrm{C}$ respectively. Prepared chicken droppings $(6 \mathrm{~kg}$ ) were mixed with $500 \mathrm{ml}$ of water to form slurry was introduced into reactor A through an inlet pipe of $50 \mathrm{~mm}$ at the top of the reactor. The synergy of the chicken droppings and the $C$. citratus was done in the ratio of $1: 1$ by mass. Thus, $3 \mathrm{~kg}$ each of prepared chicken droppings and $C$. citratus were synergized to give a total mass of $6 \mathrm{~kg}$ of both. It was mixed with $500 \mathrm{ml}$ water and was introduced into reactor $B$ through the $50 \mathrm{~mm}$ inlet pipe at the top of the reactor. C. citratus $(6 \mathrm{~kg})$ was mixed with $500 \mathrm{ml}$ of water and was introduced into reactor $C$. The slurry was allowed to occupy three quarter of the digester space leaving a clear height of about $0.0625 \mathrm{~m}$ as space for gas production. A $100-\mu \mathrm{l}$ of partly decomposed slaughter house waste (rumen content of cattle) was collected and used as seed material (inoculum) for all the reactors. The characteristics of the inoculum are shown in Table 1. A separate blank reactor containing only the inoculum and water was operated simultaneously with reactors $\mathrm{A}-\mathrm{C}$. This was used to correct the biogas volume produced from the experimental substrates. Total solids content of the three digesters was set at $7.5 \%$ following the recommendation of Ref. [23]. The inflow was directed downward to cause the solids to accumulate at the bottom of the tank for easy removal after digestion. Before feeding the reactors, the flexible hose connecting the gas outlet from the reactor, to the gas holder was disconnected, such that the gas outlet from the reactor was left open. This was done to prevent negative pressure build up in the reactor. The contents of the digesters were gently and manually stirred daily through a stirring rod attached to the digesters at $10 \mathrm{am}$ and $5 \mathrm{pm}$. The gas was collected from the digester through a $10 \mathrm{~mm}$ diameter flexible hose connected from the digester to the bottom of the gas collection system. The collected gas was allowed to pass through water and slaked lime respectively as scrubbers. Chen et al. [24] noted that slaked lime $\left(\mathrm{Ca}(\mathrm{OH})_{2}\right)$ could be used to remove carbon dioxide $\left(\mathrm{CO}_{2}\right)$ from flue gas, and that there is evidence that the $\mathrm{CO}_{2} / \mathrm{Ca}(\mathrm{OH})_{2}$ reaction also requires the uptake of water to have reaction. The overall reaction is expressed by Equation (1) as follows:

$$
\mathrm{Ca}(\mathrm{OH})_{2(s)}+\mathrm{CO}_{2(g)} \rightarrow \mathrm{CaCO}_{3(s)}+\mathrm{H}_{2} \mathrm{O}_{(l)}
$$

The gases collected before and after scrubbing were used to boil water using Ahmadu Bello University biogas stove burner [25], inorder to estimate and compare the cooking rates of biogas from the three reactors. The experiment was monitored for 30 days from 14th November, 2011 to 14th December, 2011. During this period, daily ambient temperature of Samaru-Zaria varied from $27^{\circ} \mathrm{C}$ to $37^{\circ} \mathrm{C}$ which is within the mesophilic temperature range.

\subsection{Method of measurement of gas production}

The gas holder was calibrated with the aid of a rule marked 7 in Fig. 1, to enable the reading of the daily gas production from the

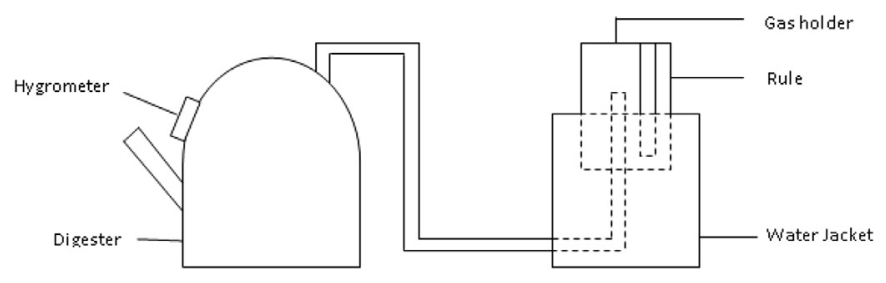

Fig. 1. Schematic sketch of the reactor with gas holder. substrates digested. The volume of biogas produced was measured each day at $4 \mathrm{pm}$ by computing the volume of the gas holder floating over water level in the water jacket.

The base area of the gas holder is expressed by Equation (2)

$A=\frac{\pi d^{2}}{4}=\frac{\pi \times 0.25^{2}}{4}=0.0491 \mathrm{~m}^{2}$

The height of cylinder above water level was read off on the rule attached to the gas holder for calibration.

Let this height $(h)=X$, which varies.

Volume of biogas $(V)$ was obtained as the volume of cylinder above water level as shown in Equation (3).

$V=\left(\frac{\pi d^{2}}{4}\right) h$

where $h=X$; substituting for $A$ in Equation (3)

$V=0.0491 X \mathrm{~m}^{3}$

\section{Results}

The quantities of biogas produced from chicken droppings (reactor A), co-digestion of chicken droppings and C. citratus (lemon grass) (reactor B), and C. citratus alone (reactor C) over a period of 30 days at an average ambient temperature of $33.1 \pm 2{ }^{\circ} \mathrm{C}$ are as presented in Fig. 2. It was observed that biogas production started in the three reactors on the second day after loading. Production of biogas in the three reactors increased gradually before it peaked on the 15th day for reactor $B$ and on the 16th day for reactors $A$ and $C$. Biogas production thereafter, dropped progressively in the three reactors. This progressive drop could be associated with the continuous decrease in substrate concentration in the reactors as a result of microbial degradation of the substrate to produce biogas. This is a typical situation with batch anaerobic digestion processes which are usually substrate limited. A total of $321 \mathrm{~L}(1.8 \mathrm{~L} / \mathrm{kg} /$ day $)$ of biogas was produced from chicken droppings. Co-digestion of chicken droppings and $C$. citratus (lemon grass) produced $236 \mathrm{~L}$ (1.3 L/kg/day) of biogas while digestion of lemon grass alone produced $170 \mathrm{~L}(1.0 \mathrm{~L} / \mathrm{kg} /$ day).

Fig. 3 shows the plot of cumulative biogas production against retention time for the three reactors. The results suggest that reactor A yielded higher total volume of biogas (321 L) than reactor

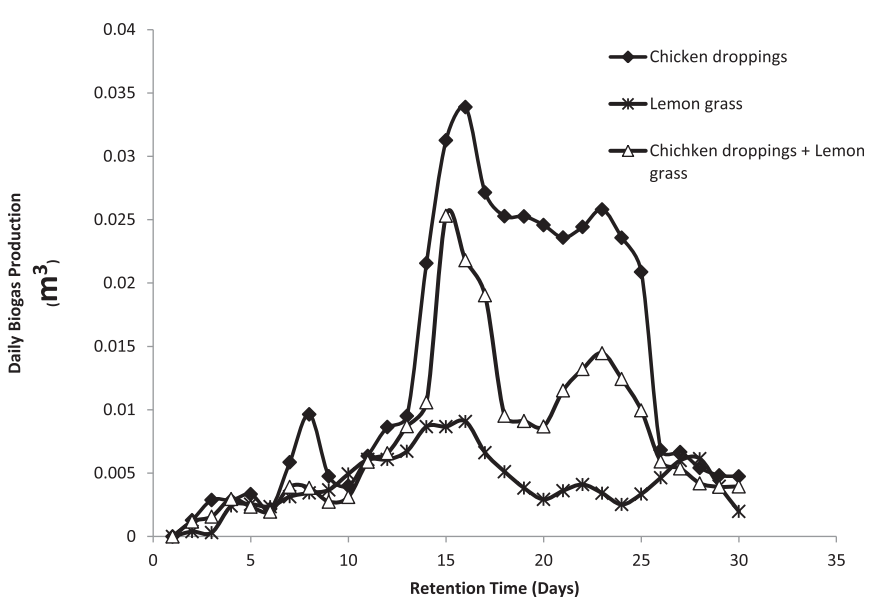

Fig. 2. Daily gas production for reactors A-C. 
Table 2

Biogas yield from chicken droppings and its co-digestion with Cymbopogon citratus (lemon grass).

\begin{tabular}{|c|c|c|c|c|}
\hline Substrate & $\begin{array}{l}\text { Total volume of biogas } \\
\text { produced }\left(\mathrm{m}^{3}\right)\end{array}$ & $\begin{array}{l}\text { Average biogas yield } \\
\text { per day }\left(\mathrm{m}^{3} / \text { day }\right)\end{array}$ & $\begin{array}{l}\text { Average yield of biogas } \\
\text { per kg of slurry }\left(\mathrm{m}^{3} / \mathrm{kg}\right)\end{array}$ & $\begin{array}{l}\text { Average daily yield of biogas } \\
\text { per } \mathrm{kg} \text { of slurry }\left(\mathrm{m}^{3} / \mathrm{kg} / \text { day }\right)\end{array}$ \\
\hline Reactor A & 0.321 & 0.011 & 0.054 & 0.002 \\
\hline Reactor B & 0.236 & 0.008 & 0.039 & 0.001 \\
\hline Reactor C & 0.170 & 0.006 & 0.028 & 0.001 \\
\hline
\end{tabular}

B (236 L) and reactor C (170 L). Also from Fig. 2, the maximum daily biogas productions for reactors $\mathrm{A}-\mathrm{C}$ were $33.89 \mathrm{~L}, 25.31 \mathrm{~L}$ and $9.08 \mathrm{~L}$ respectively.

Table 2 shows the total biogas produced, biogas yield per day, biogas yield per kg of slurry as well as the daily biogas yield per kg of slurry for each reactor. Table 2 further reveals that reactor A (chicken droppings only) had higher biogas yield per day producing $10.7 \mathrm{~L}$ /day than B (chicken droppings + C. citratus) $7.9 \mathrm{~L} /$ day and C (C. citratus alone) $6.0 \mathrm{~L} /$ day. The biogas yield per $\mathrm{kg}$ of slurry for reactors $\mathrm{A}-\mathrm{C}$ was $53.5 \mathrm{~L} / \mathrm{kg}, 39.3 \mathrm{~L} / \mathrm{kg}$ and $28 \mathrm{~L} / \mathrm{kg}$ respectively. Again, reactor A produced $1.78 \mathrm{~L} / \mathrm{kg} /$ day while B and C produced $1.3 \mathrm{~L} / \mathrm{kg} /$ day and $1.0 \mathrm{~L} / \mathrm{kg} /$ day respectively. Water and lime scrubbing were carried out on the produced gases from the three reactors to remove carbon dioxide and hydrogen sulphide impurities.

There was a reasonable drop in total volume of gas from reactors A-C after scrubbing (Fig. 4), with reactor A having the greatest drop. This implies that biogas from reactor A had more impurities than biogas from reactors B and C. Furthermore, the results of the cooking test conducted using the gases produced from the three reactors before and after scrubbing shows that reactor $\mathrm{C}$ (lemon grass alone) had the highest cooking rate $(0.079 \mathrm{~L} / \mathrm{min}$ and $0.12 \mathrm{~L} /$ min), followed by reactor $B(0.067 \mathrm{~L} / \mathrm{min}$ and $0.091 \mathrm{~L} / \mathrm{min})$ and lastly reactor $\mathrm{A}(0.060 \mathrm{~L} / \mathrm{min}$ and $0.079 \mathrm{~L} / \mathrm{min})$ as shown in Fig. 5.

\section{Discussion}

In the early stage of digestion, $\mathrm{pH}$ values of the media in all the substrates digested were slightly acidic. It however, gradually increased until it remained buffered around 7.5-8.0 when gas production was stabilized in all the reactors. In other words, the feedstocks showed a general increase in $\mathrm{pH}$ with minimal fluctuation (Fig. 6). The mean digestion $\mathrm{pH}$ values \pm standard deviation for reactors $\mathrm{A}-\mathrm{C}$ were $7.80 \pm 0.59,7.71 \pm 0.74$ and $7.38 \pm 0.74$ respectively. These mean $\mathrm{pH}$ values are within the suitable range for efficient anaerobic digestion [23]. The highest $\mathrm{pH}$ value of 9.0 was obtained in reactor B on the 14th day of digestion. Reactor C

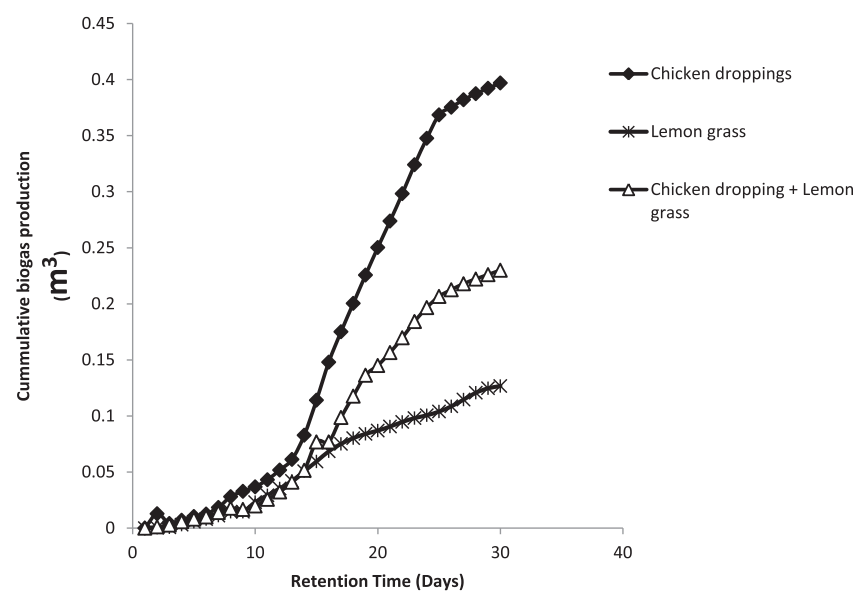

Fig. 3. Cumulative biogas production from reactors A and B. (without chicken droppings content) had the least average $\mathrm{pH}$ value in the process. The average ambient temperature of anaerobic digestion in the reactors was $33.1 \pm 2{ }^{\circ} \mathrm{C}$.

Reactor A with no lemon grass as part of its substrate produced the highest volume of biogas but had the least amount of methane following the GC analysis and cooking rate tests. It was followed by reactor B with $50 \%$ amount of lemon grass as co-substrate. Reactor $C$ with $100 \%$ lemon grass as substrate had the minimum quantity of biogas but the highest amount of methane (71.95\%). This suggests that substrates of plant origin with low biodegradability may have the potential of producing higher quality biogas. The higher and faster biogas generation in reactor A could be attributed to the faster rate of decomposition of animal intestinal wastes which have already undergone a form of digestion in the digestive system of the chickens hence, hydrolysis may not have been the rate limiting step in reactor $A$.

The action of bacteria on this category of waste was fast relative to the lemon grass that had much lignin content. The higher biogas production from chicken droppings could also be attributed to the available nutrient in the droppings, organic matter and high microbial biomass unlike lemon grass [26]. This is in accordance with

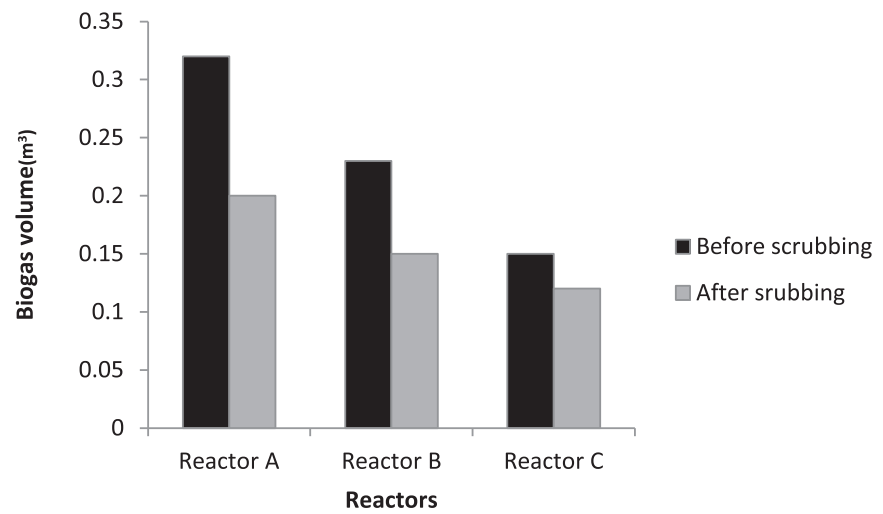

Fig. 4. Volume of biogas from reactors A and B before and after scrubbing.

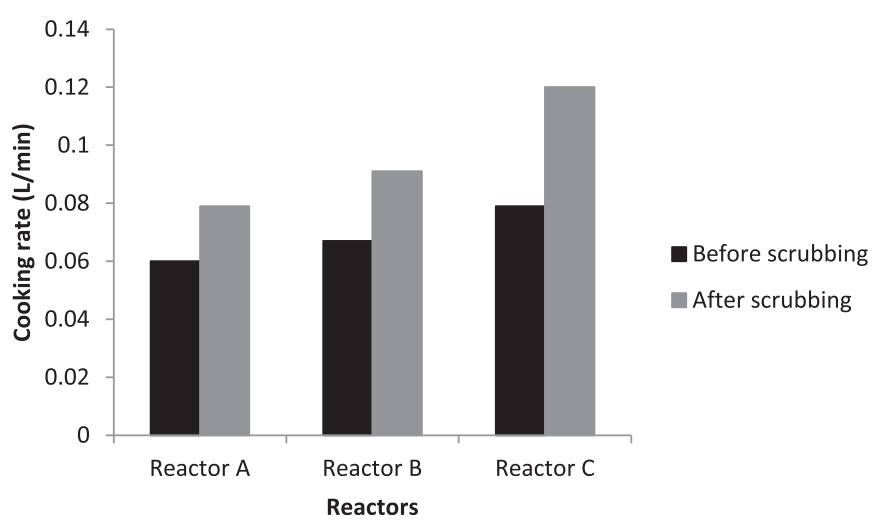

Fig. 5. Comparative biogas cooking rates before and after scrubbing. 


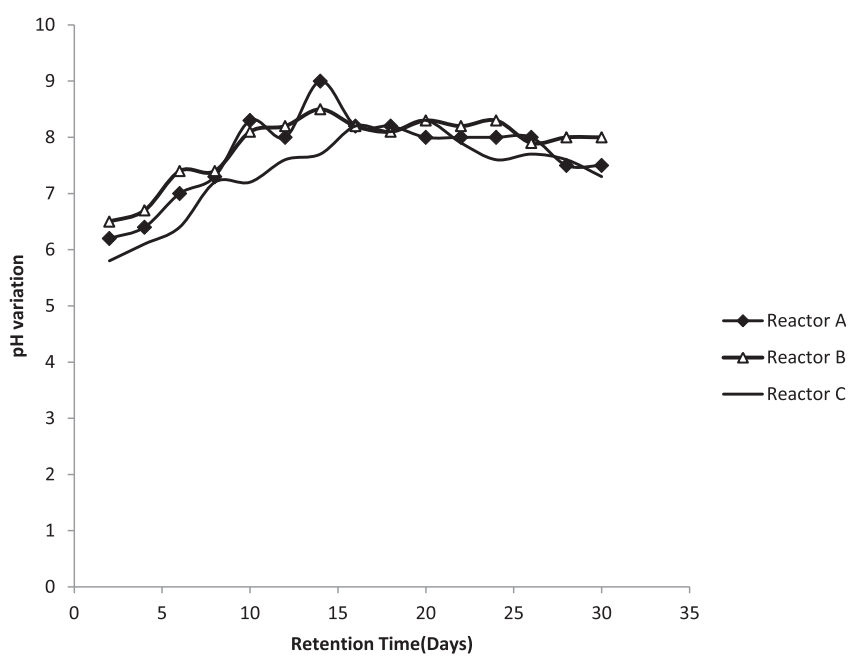

Fig. 6. Variation in $\mathrm{pH}$ with anaerobic digestion time.

the report of Ojolo et al. [27] that substrates should contain adequate amount of carbon, oxygen, hydrogen, nitrogen, sulfur, phosphorous, potassium, calcium, magnesium and a number of trace elements for a better biodegradability. Lemon grass was reported to have $11 \%$ permanganate lignin and 58\% holocellulose fraction [28], indicating that hydrolysis could have been the rate limiting step for lemon grass digestion and could have contributed to the slower and lower biogas production in reactors $B$ and $C$. However, digestion above the retention period of 30 days utilized in this study could result in higher biogas yield for reactors $B$ and $C$ as the total solids (TS) content of the effluents was relatively higher than the TS content of effluent from reactor A. Extensive chemical or enzymatic pretreatment is recommended for the anaerobic digestion of lemon grass. Total biogas production obtained in this work is $321 \mathrm{~L}$ for reactor A, $236 \mathrm{~L}$ for reactor B and $170 \mathrm{~L}$ for reactor C. These results are in agreement with the results in Rulz et al. [28].

The initial slow rate of gas production and subsequent peak in the 15th day for reactor $\mathrm{A}$, and in the 16th day for reactors $\mathrm{B}$ and $\mathrm{C}$ respectively could be attributed to the time taken for bacteria adaptation to the complex biomass [23].

The methane content of biogas produced from the three reactors generally increased with time of digestion. This could be attributed to the accumulation of intermediates in the early stage of digestion that could have inhibited methanogenic bacteria. Similar observation was reported by El-Mashad and Zhang [29]. The lowest methane content of $15 \%$ was obtained in reactor $\mathrm{A}$, after the first 4 days of digestion. The highest methane content of about $76 \%$ was obtained in reactor $\mathrm{C}$ at retention time of 30 days. Reactor B had its lowest methane content (18\%) and highest methane content (72\%) in the 3rd and 30th day of digestion. The average methane contents and standard deviations for reactors $\mathrm{A}-\mathrm{C}$ after 30 days retention period were $45.71 \pm 10.2 \%, 66.20 \pm 9.8 \%$ and $71.95 \pm 15.3 \%$ respectively. It was observed from this study that the average methane content of biogas from chicken droppings increased from $45.71 \%$ to $66.20 \%$ when it was co-digested with C. citratus (lemon grass) which indicates a significant improvement in gas quality. The average methane content of reactor $C$ was $71.95 \%$. This value is higher than most values reported in literature for many energy plants indicating that lemon grass could be a good co-substrate to high yield substrates of animal origin for the achievement of high quality biogas needed for the economic viability of industrial anaerobic plants.

The higher cooking rates observed in reactors $B$ and $C$ before and after scrubbing as shown in Fig. 5 could be attributed to their higher methane content. The cooking rates of gases from reactors $\mathrm{A}-\mathrm{C}$ improved by $31.71 \%, 45.8 \%$ and $51.9 \%$ respectively after the gases were scrubbed using water and slaked lime. The main limitation of using chicken manure for renewable energy generation (biogas) despite its relatively high yield of biogas is that it produces a high proportion of hydrogen sulphide and other impurities as well. Hydrogen sulphide even when present in small proportions corrodes metal fittings while carbon dioxide reduces the heating value of biogas. Co-digesting chicken droppings with $C$. citratus could help in reducing these impurities significantly. Detailed comparison of the result of this work with the works of previous authors was difficult because works on co-digestion of animal manure with C. citratus in literature is either scanty or non-existent. However, a loose comparison of the results of this study with that of previous authors [30-34] is shown in Table 3.

From Table 3, biogas yield from reactor $C$ is relatively higher than the yield of some reported co-digestion experiments in literature.

\section{Conclusion}

Though chicken droppings digested alone produced more volume of biogas than when it was co-digested with $C$. citratus (lemon grass), methane content was however higher in the co-digestion regime with $C$. citratus. Quality of biogas from chicken droppings can be improved by anaerobic co-digestion with $C$. citratus (lemon grass). Biogas from the mono digestion of $C$. citratus in reactor $C$ had both the highest methane content and cooking rate. This study could not establish if longer retention period for the co-digestion would increase the biogas yield although it is inferred that it would allow for proper decomposition of the lemon grass and consequently higher biogas yield. Co-digestion of animal waste with some energy plants could contribute to improving the quality of biogas in industrial anaerobic plants thereby improving on the economics of the process.

Table 3

Results of present study versus previous studies.

\begin{tabular}{|c|c|c|c|c|c|}
\hline $\mathrm{S} / \mathrm{N}$ & Substrate & Average Biogas/methane yield & Type of Reactor & Scale of Reactor & Author(s)/References \\
\hline 1 & Field grass + Poultry dropping & $5.07 \mathrm{~L} / \mathrm{kg}$ : biogas & Anaerobic & Pilot Scale & [19] \\
\hline $2 a$ & Unscreened dairy manure & $241 \mathrm{~L} / \mathrm{kg}$ VS: biogas & Anaerobic & Pilot Scale & {$[22]$} \\
\hline $2 \mathrm{~b}$ & Cornstalk & $217.60 \mathrm{~L} / \mathrm{kg}$ Ts added: methane & Anaerobic & Pilot Scale & [29] \\
\hline 3 & Vermicompost + Cornstalk & $410.03 \mathrm{~L} / \mathrm{kg}$ Ts added: methane & Anaerobic & Pilot Scale & [29] \\
\hline 4 & Solid waste from potato processing & $0.65 \times 10^{-4} \mathrm{~L} / \mathrm{kg}:$ methane & Anaerobic & Pilot Scale & [30] \\
\hline 7 & Enzyme pretreated sugar beet pulp & 6.11 L/kg: biogas & Anaerobic & Pilot Scale & [31] \\
\hline 8 & Enzyme pretreated spent hop & $4.05 \mathrm{~L} / \mathrm{kg}$ : biogas & Anaerobic & Pilot Scale & [31] \\
\hline 9 & Poultry manure + municipal sewage sludge & 384 L/kg VS: biogas & Anaerobic & Pilot Scale & [32] \\
\hline 10 & Food waste + human excreta & $56.5 \mathrm{~L} / \mathrm{kg}$ : biogas & Anaerobic & Pilot Scale & [33] \\
\hline $11 \mathrm{a}$ & Chicken dropping & 54 L/kg (biogas); 33.3 L/kg (methane) & Anaerobic & Pilot Scale & Present study \\
\hline $11 b$ & Chicken dropping + Cymbopogon citratus & $39 \mathrm{~L} / \mathrm{kg} /($ biogas); $25.8 \mathrm{~L} / \mathrm{kg}$ (methane) & Anaerobic & Pilot Scale & Present study \\
\hline $11 \mathrm{c}$ & Cymbopogon citratus & $28 \mathrm{~L} / \mathrm{kg} /($ biogas); $21.6 \mathrm{~L} / \mathrm{kg} /($ methane $)$ & Anaerobic & Pilot Scale & Present study \\
\hline
\end{tabular}




\section{References}

[1] Okeh OC, Onwosi OC, Odibo FJ. Biogas production from rice husks generated from various rice mills in Ebonyi State Nigeria. Renew Energy 2013:62:204-8.

[2] Thakur IS. Environmental biotechnology: basic concept and applications. New Delhi: Ik International Pvt Ltd; 2006.

[3] Alfa MI, Okuofu CA, Adie DB, Dahunsi SO, Oranusi SO, Idowu SA. Evaluation of biogas potentials of Cymbopogon citratus as alternative energy in Nigeria. Int J Green Chem Bioproc 2012;2(4):34-8.

[4] Owamah HI, Asiagwu AK, Egboh SHO, Phil-Usiayo S. Drinking water quality at Isoko North communities of the Niger Delta Region, Nigeria. Toxicol Environ Chem 2013;95(7):1116-28.

[5] WHO, World Health Organization, United Nations Children's Emergency Fund Water for life: making it happen. Joint Monitoring Programme for Wate Supply and Sanitation; 2005.

[6] Fernandez A, Sanchez A, Font X. Anaerobic co-digestion of a simulated organic fraction of municipal solid wastes and fats of animals and vegetable origin. Biochem Eng J 2005;26:22-8.

[7] Rongpin Li-Shulin, Chen Xiujin L, Saifullah L, Yangfeng H. Anaerobic codigestion of kitchen waste with cattle manure for biogas production. Energy Fuels 2009;23:2225-9.

[8] Kaparaju P, Rintala J. Anaerobic co digestion of potato tuber and its industrial byproducts with pig manure. Resour Conserv Recycl 2005;43:175-88.

[9] Ritz M, Bergamasco R, Tavares C. Anaerobic co-digestion of fruit and vegetable waste and sewage sludge. Int J Chem Reactor Eng 2007:5.

[10] Gomez X, Cuetos M, Cara J, Moran A, Garcia A. Anaerobic co-digestion of primary sludge and the fruit and vegetable fraction of the municipal solid wastes conditions for mixing and evaluation of the organic loading rate. Renew Energy 2006;31:2017-24.

[11] Fantozzi F, Buratti C. Biogas production from different substrates in an experimental continuously stirred reactor anaerobic digester. Bioresour Technol 2009:100:5783-9.

[12] Mshandete A, Kivaisi A, Rubindamayugi M, Mattiasson B. Anaerobic batch codigestion of sisal pulp and fish wastes. Bioresour Technol 2004;95(1):19-24.

[13] Parawira W, Murto M, Zvauya R, Mattiasson B. Anaerobic batch digestion of solid potato waste alone and in combination with sugar beet leaves. Renew Energy 2004;29:1811-23.

[14] Akhila A. Essential oil-bearing grasses: the genus Cymbopogon. CRC Press; Taylor and Francis Group; 2009.

[15] Sugumaran M, Joseph S, Lee KLW, Wong KW. Herbs of Malaysia. Shah Alam: Federal Publication; 2005.

[16] Tajidin NE, Ahmad SH, Rosenani AB, Azimah H, Munirah M. Chemical composition and citral content in lemongrass (Cymbopogon citratus) essential oil at three maturity stages. Afr J Biotechnol 2012;11(11):2685-93.
[17] Fountoulakis MS, Drakopoulou S, Terzakis S, Georgaki E, Manios T. Potential for methane production from typical Mediterranean agro-industrial byproducts. Biomass Bioenergy 2008;32:155-61. .s.

[18] APHA. Standard methods for examination of water and waste-water. 22nd ed. Washington, DC: American Public Health Association; 2012.

[19] Uzodinma EO, Ofoefule AU. Biogas production from blends of field grass (Panicum maximum) with some animal wastes. Int J Phys Sci 2009;4(2):0915 .

[20] Karki A. From kitchen waste to biogas: an empirical experience. Biogas and Natural Resources Management; 2002. No. 75.

[21] Owen WF, Stuckev DC, Healv JB, Young Jr LY, Mccagrv PL. Bioassay for monitoring biochemical methane potential and anaerobic toxicity. Water Res 1979;13:485-92.

[22] Zhang R, El-Mashad HM, Hartman K, Wang F, Liu G, Choata C, et al. Characterization of food waste as feedstock for anaerobic digestion. Bioresour Technol 2006:98(4):929-35.

[23] Momoh OLY, Anyata BU, Saroj DP. Development of simplified anaerobic digestion models (SADM's) for studying anaerobic biodegradability and kinetics of complex biomass. Biochem Eng 2013;79:84-93.

[24] Chen B, Laucks ML, Davis EJ. Carbon dioxide uptake by hydrated lime aerosol particles aerosol. Sci Technol 2004;38:588-97.

[25] Igboro SB, Okuofu CA, Ahmadu TO, Otun JA. Development and evaluation of a biogas stove. Niger J Eng 2011;17(2).

[26] Ahmadu TO, Folayan CO, Yawas DS. Comparative performance of cow dung and chicken droppings for biogas production. Niger J Eng 2009;16(1):154-64.

[27] Ojolo SJ, Dinrifo RR, Adesuyi KB. Comparative study of biogas production from five substrates. Adv Mater Res J 2007;18-19:519-25.

[28] Rulz C, de Leon R, de Arriola MC, de Cabrera S. Biodelinification of lemon grass and citronella bagasse by white-rot fungi. Appl Environ Microbiol 1986;52(4): 607-11.

[29] El-Mashad HM, Zhang R. Biogas production from co-digestion of diary manure and food waste. Bioresour Technol 2010;101:4021-8.

[30] Chen G, Zheng Z, Yang S, Fang C, Zou X, Luo Y. Experimental co-digestion of corn stalk and vermicompost to improve biogas production. Waste Manag 2010;30:1834-40.

[31] Linke B. Kinetic study of thermophilic anaerobic digestion of solid wastes from potato processing. Biomass Bioenergy 2006:30:892-6.

[32] Zieminski K, Romanowska I, Kowalska M. Enzymatic pretreatment of lignocellulosic wastes to improve biogas production. Waste Manag 2012;32:11317.

[33] Borowski S, Wetherley L. Co-digestion of solid poultry manure with municipal sewage sludge. Bioresour Technol 2013;142:345-52.

[34] Dahunsi SO, Uranusi US. Co-digestion of food waste and human excreta for biogas production. Br Biotechnol J 2013;3(4):485-99. 